\title{
Sorption Studies of Radioiodine on Soils with Special References to Soil Microbial Biomass
}

\author{
By J. Bors ${ }^{1}$, H. Erten ${ }^{2}$ and R. Martens ${ }^{3}$ \\ 1 Lower Saxony Institute of Radioecology, at the Hannover University, Herrenhäuser Str. 2, D-3000 Hannover, FRG \\ 2 Department of Chemistry, Bilkent University, Ankara-Turkey \\ 3 Institute of Soil Biology, Federal Research Center for Agriculture, Braunschweig, FRG
}

(Received November 6, 1989; revised February 23, 1990)

\section{Radioiodine / Sorption / Microbial biomass / Soils / Clays}

\begin{abstract}
In batch experiments with two types of soils, chernozem and podzol, radioiodine $\left({ }^{125} \mathrm{I}\right)$ showed an initial rapid sorption, followed by a long and slow further increase. Very little sorption $\left(R_{d}<1\right)$ was detected in clay minerals. Generally, higher $R_{d^{-}}$ values were observed for the chernozem soil, characterized by a higher amount of organic substance and of soil biomass. The sorption process was predominantly irreversible, the isotherms were linear at low ion concentrations and deviated from linearity starting at $10^{-5} \mathrm{mmol} \cdot \mathrm{ml}^{-1}$. Sorption ratio was found to increase with increasing volume to mass ratio. The composition of liquid phases (bidistilled water, synthetic soil water, rain water) highly affected iodine sorption. In experiments with $\mathrm{KBr}$ solution, the sorption of $\mathrm{I}^{-}$was found to be strongly preferred to $\mathrm{Br}^{-}$.

Incubation of soil samples under varied conditions (decreased or increased soil biomass, $\mathrm{O}_{2}$-concentration, incubation temperature, soil water content and storage conditions) delivered indications for the participation of soil microflora in iodine immobilization. Test with isolated soil bacteria and fungi showed that radioiodine can be incorporated by soil microorganisms under certain conditions only: Considerable uptake of radioiodine was found in washed $\left(\mathrm{NaCl}, \mathrm{CaCl}_{2}\right)$ cells with both bacteria and fungi, but no incorporation was detected into cells incubated with radioiodine in the culture medium.
\end{abstract}

\section{Introduction}

The quantitative description of the migration rate of iodine isotopes, especially the long lived ${ }^{129} \mathrm{I}$, in soil, requires the knowledge of the relevant soil parameters and their participation in iodine sorption. The understanding of the mechanisms of iodine immobilization and remobilization processes would help to introduce safety measures in order to minimize radioecological consequences.

Sorption studies of iodine on soils and minerals have been carried out by several investigators $[1-6]$. However, in some of these studies high concentrations of stable iodine were used and the results may not be applicable to the trace amounts of iodine in soils possible arising from ${ }^{129} \mathrm{I}$ depositions from nuclear facilities $[3,4]$. In particular very little information is available on the process of desorption. In general, it was demonstrated, that soil organic matter is chiefly involved in the geochemistry of radioiodine $[1-4,7$,
$8,9]$. Because of the known interaction of soil organic matter and soil biomass the participation of microorganisms in iodine immobilization processes was suggested [10, 11, 12]. However, in these studies sterilization techniques such as autoclaving or gamma irradiation, have been applied which do not only eliminate microbial activity but also affect other nonliving soil constituents. Therefore the clear separation of geochemical and biological processes remained unsatisfactory.

In this work, the sorption and desorption behaviour of radioiodine on two different soil types was studied using a wide range of iodide concentrations. In particular, the contribution of soil biomass on radioiodine immobilization processes was investigated. The conceptual approach to elucidate the participation of soil microorganisms was the incubation of soil samples under conditions which are not expected to alter the non-living soil parameters (addition of glucose) or do so to very limited extent $\left(\mathrm{CHCl}_{3}-\right.$ fumigatien, air drying of soil samples, different incubation temperatures) only.

As a further test for microbial effects, incorporation experiments were carried out with isolated soil bacteria and fungi.

\section{Materials and methods}

The soils used in the experiments were of the chernozem (clay silt soil) and podzol (humus sandy soil) types. The characteristics of the soils are given in Table 1. In each case the samples were taken from the upper $20 \mathrm{~cm}$ horizon of natural profile and were sieved $(<2 \mathrm{~mm})$ before use. Clay minerals from Turkey used in sorption studies were koalinite, montmorillonite and chlorite-illite. ${ }^{125} \mathrm{I}$ was used as tracer in the initial concentrations of $1 \cdot 10^{-8}$ to $1 \cdot 10^{-3} \mathrm{~mol} \cdot 1^{-1}$. It was obtained from Amersham International, Amersham Buchler GmbH, Braunschweig (Code IMS.30). The initial activity was $3.7 \mathrm{GBq} \cdot \mathrm{ml}^{-1}$, the volume $1 \mathrm{ml}$ and $\mathrm{I}^{-1}$ ion concentration $7.6 \mu \mathrm{gI} \cdot \mathrm{ml}^{-1} .10 \mu \mathrm{l}$ of the tracer solution were added to $100 \mathrm{ml}$ of $0.1 \mathrm{M} \mathrm{NaOH}$. The solution was divided into five $20 \mathrm{ml}$ portions. Nothing was added to the first portion, $1 \mathrm{ml}$ solutions containing $0.164 \mathrm{mg} \mathrm{KI} \cdot \mathrm{ml}^{-1}, 1.64 \mathrm{mg} \mathrm{KI} \cdot \mathrm{ml}^{-1}$, $16.4 \mathrm{mg} \mathrm{KI} \cdot \mathrm{ml}^{-1}$ and $164 \mathrm{mg} \mathrm{KI} \cdot \mathrm{ml}^{-1}$ were added 
Table 1. Characteristics of the soils used in the experiments

\begin{tabular}{lcccccc}
\hline Soil type/location & $\begin{array}{c}\text { Sand } \\
(\%)\end{array}$ & $\begin{array}{c}\text { Silt } \\
(\%)\end{array}$ & $\begin{array}{c}\text { Clay } \\
(\%)\end{array}$ & $\begin{array}{c}\mathrm{C}_{\text {org }} \\
(\%)\end{array}$ & $\begin{array}{c}\mathrm{pH} \\
(\mathrm{n}- \\
\mathrm{KCl})\end{array}$ & $\begin{array}{c}\text { Bio- } \\
\text { mass } \\
\mu \mathrm{gC}\end{array}$ \\
\hline $\mathrm{g}^{-1}$
\end{tabular}

Table 2. Composition of synthetic soil water and rain water used in the sorption studies

\begin{tabular}{lcc}
\hline Ions & \multicolumn{2}{c}{ Ion concentration $\left(\mathrm{mg} \cdot \mathrm{l}^{-1}\right)$} \\
\cline { 2 - 3 } & $\begin{array}{c}\text { Synthetic soil water } \\
\text { (SSW) }\end{array}$ & Rainwater \\
\hline $\mathrm{Na}^{+}$ & 148.7 & 0.8 \\
$\mathrm{~K}^{+}$ & 95.8 & 0.4 \\
$\mathrm{NH}_{4}^{+}$ & - & 1.1 \\
$\mathrm{Ca}^{2+}$ & 274.5 & 0.6 \\
$\mathrm{Mg}^{2+}$ & 44.0 & 0.2 \\
$\mathrm{Cl}^{-}$ & 486.4 & 1.5 \\
$\mathrm{NO}_{3}^{-}$ & 553.0 & 4.3 \\
$\mathrm{SO}_{4}^{2-}$ & 173.9 & 5.3 \\
$\mathrm{pH}$ & 6.1 & 4.2 \\
\hline
\end{tabular}

to the second, third, fourth and fifth portions respectively. All samples were then filled to the $100 \mathrm{ml}$ mark with bidistilled water. In other series of experiments the stock solutions were prepared using synthetic soil water (SSW) and rain water as the diluting solution. SSW has a composition similar to the soil water below maximum water holding capacity of the region where soil samples were taken. Table 2 gives the composition and characteristics of the water samples used.

The sorption experiments were carried out using the batch method [13]. $5 \mathrm{~g}$ of duplicate soil samples were suspended in centrifuge tubes in $10 \mathrm{ml}$ of iodine ion solution prepared by $1: 100$ dilution of stock solution and shaken for 8 days or longer at $22^{\circ} \mathrm{C}$. After separation of the two phases by centrifugation $(6000 \mathrm{rpm})$ and filtration $(0.22 \mu \mathrm{m})$ concentration change of the adsorbate in the aqueous phase was determined radiochemically using a $\mathrm{NaI}(\mathrm{Tl})$ detector. The distribution ratio $R_{d}$ was calculated from the measured activities before and after shaking using the equations given in ref. [13].

For desorption studies, following the adsorption step, after separation of the two phases, $10 \mathrm{ml}$ of water (bidistilled, SSW, or rain water) was added to the sample tube, shaken for the desired time, separated and counted as described above. Exchange experiments were carried out by shaking inactive solutions of various $\mathrm{I}^{-}$concentrations for eight days. After phase separation carrier free iodine tracer solution was added to the solid phase and the samples were shaken for further eight days. From the decrease in the activity of the liquid phase $R_{d, \text { ex }}$ of the $\mathrm{I}^{-}$exchange was calculated.

To investigate the effects of soil biomass in iodine immobilization $10 \mathrm{~g}$ each of triplicate soil samples were suspended either in $20 \mathrm{ml}$ of distilled water or synthetic soil water containing $63 \mathrm{kBq}$ of ${ }^{125} \mathrm{I}$ $\left(\sim 10^{-12} \mathrm{~mol} \mathrm{I}^{-1}\right)$. After shaking for at least 8 days solid and liquid phases were separated as described above. Standard errors in the batch experiments were below $5 \%$, unless otherwise stated.

To investigate the effect of different incubation conditions soil samples were incubated with ${ }^{125} \mathrm{I}$ under aerobic and anaerobic $\left(\mathrm{N}_{2}\right)$ conditions. These effects were compared with soil samples which had been pretreated to reduce or eliminate soil biomass. Sterility was achieved by ${ }^{60} \mathrm{Co}$ gamma-irradiation $(40 \mathrm{KGy})$ or by $\mathrm{CHCl}_{3}$-fumigation. In another set of experiments tests about the influence of microorganisms on iodine immobilization were carried out to find a possible temperature optimum of the considered process. Soil samples were incubated for $8 \mathrm{~d}$ at $4,10,16,20,24,28$ and $36^{\circ} \mathrm{C}$ before determination of the $R_{d}$-values.

Indications on biological contributions to the iodine behaviour were also expected from the effects of different pretreatments of the two soil types. Soil samples were a) taken freshly from the field with moisture contents of 20 and $9 \%$ for chernozem and podzol, respectively, b) air dried within few days and c) stored in the laboratory $\left(22^{\circ} \mathrm{C}\right)$ for about one year before use in the investigation of the $R_{d}$-values.

To study the influence of the quantity of soil biomass on iodine sorption soil samples of increased and reduced biomass were included in the batch experiments. The increase was achieved by the addition of glucose (about $20-30 \%$ of the added glucose-C is converted into biomass-C), and the reduction was obtained by fumigation with $\mathrm{CHCl}_{3}$. Soil biomass was determined as described by Jenkinson and Powlson [14]. To test possible depletion effects, carrier iodine (KI) in concentrations of $10^{-8}$ to $10^{-3} \mathrm{mols} \cdot 1^{-1}$ was added to distilled water and synthetic soil water. After incubation and separation of phases $\boldsymbol{R}_{d}$-values were calculated for a chernozem soil as described above.

Further, incorporation experiments were carried out with isolated soil bacteria (Enterobacter sp., Bacillus sp. and Pseudomonas sp.) and fungi (Thielaviopsis sp., Verticillium sp., Fusarium sp., Trichoderma sp. and Penicillium sp.). The microorganisms were cultured either in complex or synthetic liquid medium. The synthetic medium was unbuffered or buffered with tris-buffer or phosphate-buffer for $\mathrm{pH}>7$. $12.5 \mathrm{kBq}{ }^{125} \mathrm{I}$ was added to $20 \mathrm{ml}$ nutrient solution in $50 \mathrm{ml}$ Erlenmeyer flasks either directly after the inoculation of the culture or after sufficient growth (bacteria $=10^{8}$ cells $\cdot \mathrm{ml}^{-1}$, fungi $=10 \mathrm{mg} \cdot \mathrm{ml}^{-1}$ dry wt.). Adsorption was also investigated with harvested microbial cells which were either washed with $\mathrm{H}_{2} \mathrm{O}$ or $\mathrm{CaCl}_{2}(0.01 \mathrm{M})$ or $\mathrm{NaCl}(0.15 \mathrm{M})$ to remove extraneous materials. For incorporation experiments organisms were suspended in these liquids containing 
the radioiodine. After incubation of dupliate samples for 3 days cells were separated by centrifugation $(10,000 \mathrm{~g})$.

\section{Results and discussion}

\subsection{Sorption studies}

The results of the kinetic studies are shown for chernozem and podzol soils in Fig. 1 and Fig. 2, respectively. In both soil types higher sorption is observed with synthetic soil water than with bistilled water. The initial sorption rate is much faster for podzol than for chernozem and reaches near steady state after about 4 days, while in chernozem the sorption process is slower and continues over the whole time period studied. This behaviour suggests the influence of organic components and microorganisms which are present in higher amounts in chernozem soil (Table 1). The adsorption as well as desorpiton results as a function of $\mathrm{I}^{-}$ion loading in the solid phase for the two differ- ent soil types are shown in Figs. 3 and 4 for chernozem and podzol, respectively. If the sorption values are taken to be true equilibrium constants, then they are not expected to show a variation with $\mathrm{I}^{-}$concentration. It is seen in Figs. 3 and 4 that such constant sorption values exist for both soils. These regions extend to $\mathrm{I}^{-}$ion concentrations of up to about $10^{-5}$ mmols $\cdot \mathrm{g}^{-1}$ for chernozem and up to $5 \cdot 10^{-3} \mathrm{mmols}$ $\cdot \mathrm{g}^{-1}$ for podzol. The difference in the sorption properties of $\mathrm{I}^{-}$ion with different sorption solutions is much more pronounced in the desorption than the adsorption results. Sorption is observed to be quite irreversible in the case of bidistilled water and reversible to a large extent for synthetic soil water and rainwater. It is interesting to observe the existence of an unexpected high $R_{d}$-region around $5 \cdot 10^{-3} \mathrm{mmols} \cdot \mathrm{g}^{-1}$ both in the adsorption and desorption results for podzol soil. The pronounced increase in the sorption values suggests a change in the sorption mechanism which tends towards complete reversibility for all three types of sorption solutions used. To test the validity of this

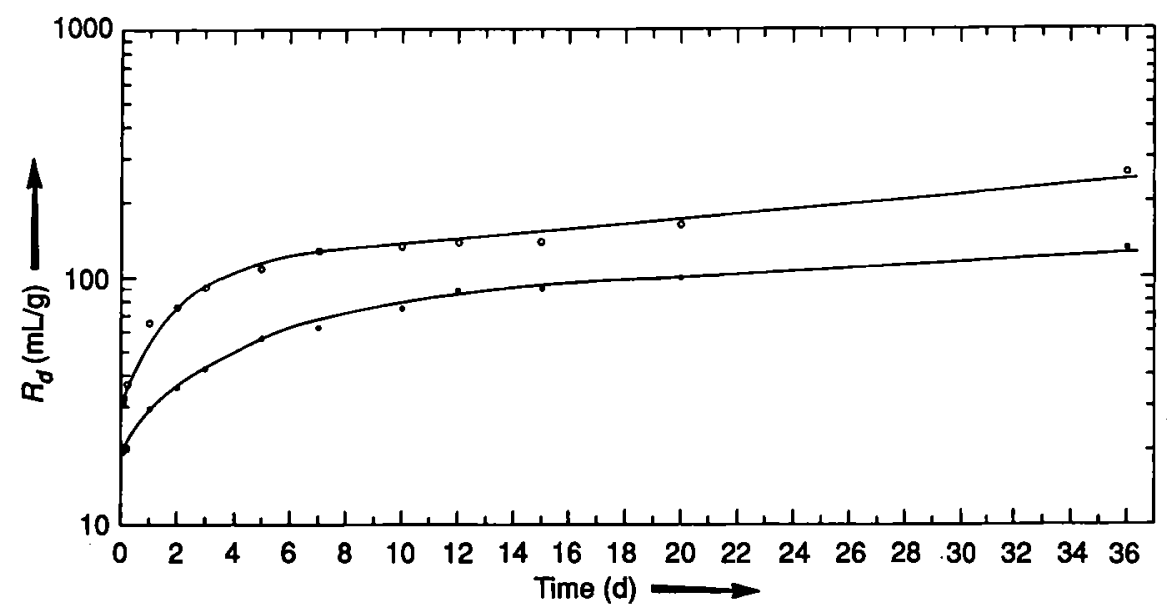

Fig. 1. Change of $R_{d}$ with time for Chernozem soil. Initial iodine concentration, $\left(\mathrm{I}^{-}\right)_{0}=1.0 \cdot 10^{-8} \mathrm{~mol} \cdot \mathrm{I}^{-1}$. $\mathrm{bidistilled}$ water; $\odot$ synthetic soil water.

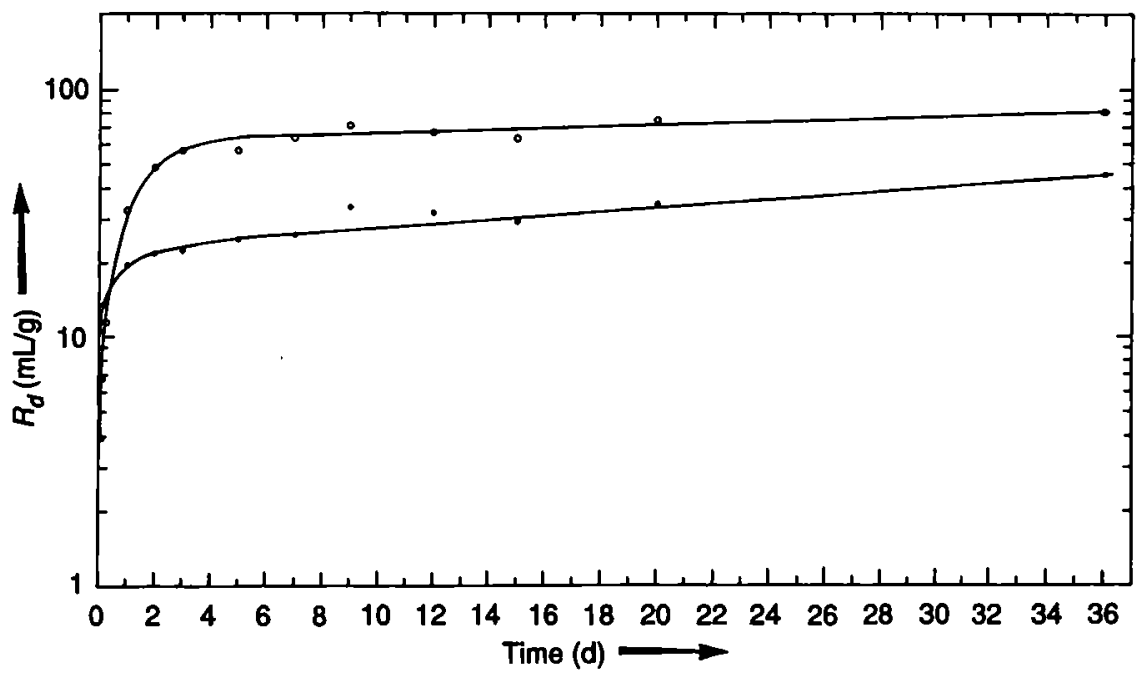

Fig. 2. Change of $R_{d}$ with time for Podzol soil. Initial iodine concentration $\left(\mathrm{I}^{-}\right)_{0}=1.0 \cdot 10^{-8} \mathrm{~mol} \cdot 1^{-1}$. bidistilled water; $O$ synthetic soil water. 

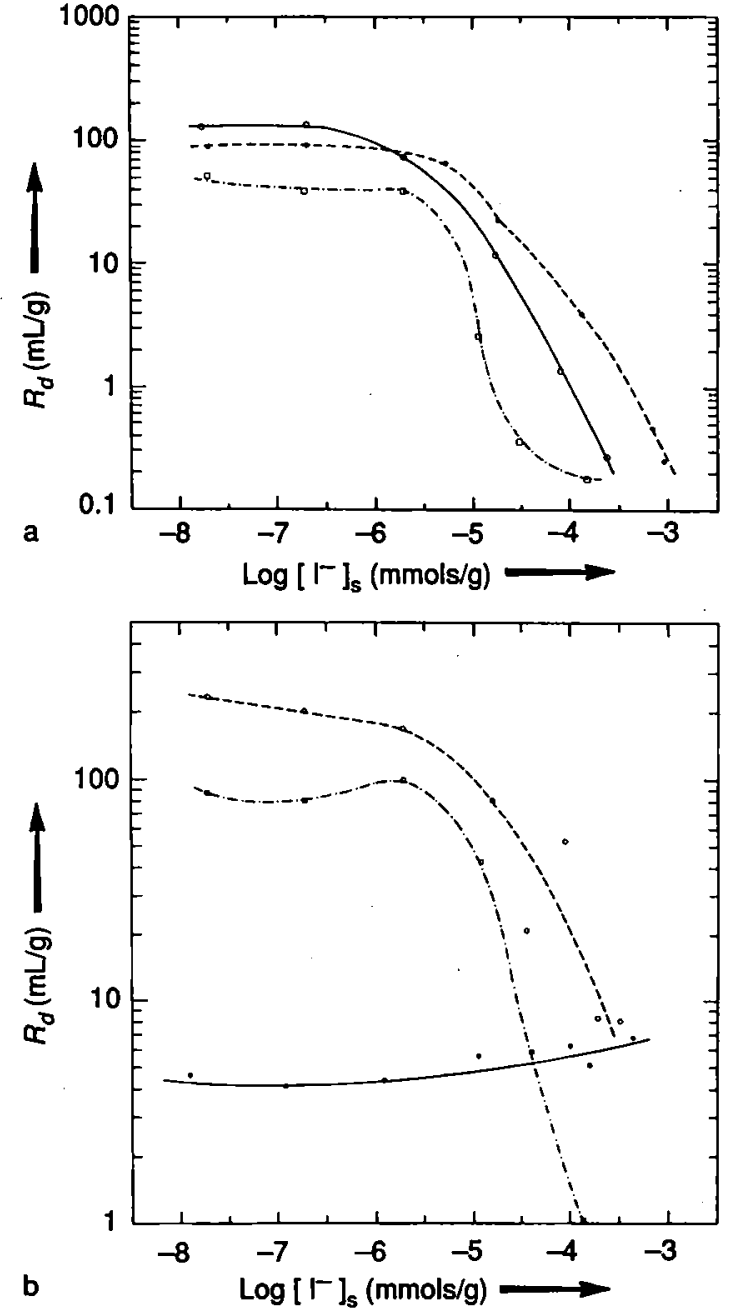

Fig. 3. Change of $R_{d}$ values with $\mathrm{I}^{-}$ion loading for Chernorem soil. bidistilled water; $O$ synthetic soil water; $\otimes$ rainwater; a) adsorption; b) desorption.

observation tests were repeatedly carried out and revealed the same results. More work is needed to better understand and explain this experimentally observed high $R_{d}$-region.

The sorption isotherms for chernozem and podzol are shown in Figs. 5 and 6, respectively. The results for chernozem show deviations from linearity at high concentrations. Furthermore, reversible sorption is lower for chernozem than for podzol soils. Except for the high $R_{d}$-region discussed above the isotherms are linear for podzol. The adsorption and desorption results are close to each other for synthetic soil water and rainwater, indicating reversibility.

The results of the sorption of $\mathrm{I}^{-}$ion in synthetic soil water onto chernozem and podzol as a function of water volume to soil mass ratio, are shown in Fig. 7. An initial strong dependence of $R_{d}$ on $\mathrm{V} \cdot \mathrm{m}^{-1}$ is observed between $\mathrm{V} \cdot \mathrm{m}^{-1}=2$ to about 10 for both soil types. The gradual increase of $R_{d}$ at $\mathrm{V} \cdot \mathrm{m}^{-1}=10$ and higher is more pronounced for chernozem than podzol soil. Increasing the volume to mass ratio, probably better disperses and exposes the soil particles and their organic components to ions in solution resulting in
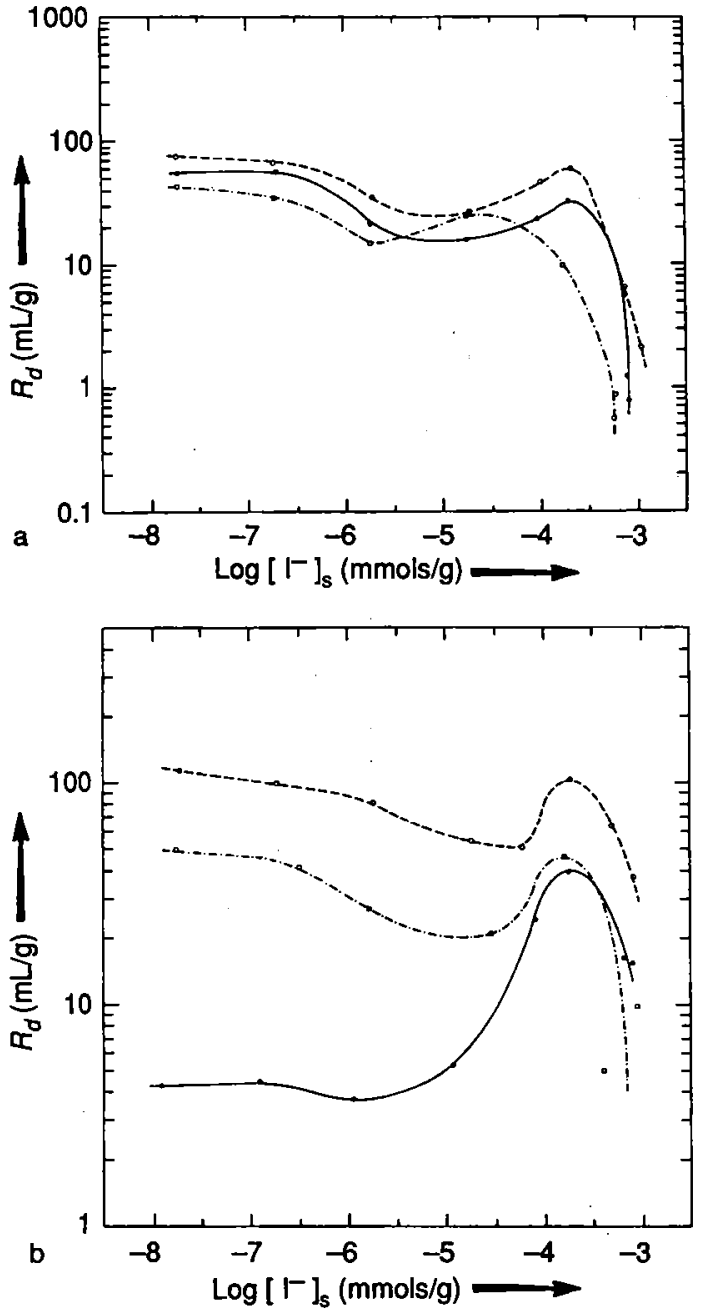

Fig. 4. Change of $R_{d}$ values with $\mathrm{I}^{-}$ion loading for Podzol soil. bistilled water; $O$ synthetic soil water; $\otimes$ rainwater; a) adsorption; b) desorption.

increasing sorption values. The presence of higher carbon content and microorganisms lead to higher $R_{d}$ values for chernozem.

The effect of the presence of different electrolytes in solution on the sorption of $\mathrm{I}^{-}$has also been studied. Various concentrations of $\mathrm{KBr}, \mathrm{KCN}, \mathrm{KNO}_{3}$ and $\mathrm{K}_{2} \mathrm{SO}_{4}$ have been used in the aqueous phase with no $\mathrm{I}^{-}$carrier added. Contrary to loading experiments with inactive $\mathrm{KI}$ as shown in Figs. 3 and 4, the distribution ratio $R_{d}$ remains constant at varying $\mathrm{Br}^{-}, \mathrm{CN}^{-}$, $\mathrm{NO}_{3}^{-}$and $\mathrm{SO}_{4}^{2-}$ ion concentration. (Data not shown). The sorption process is reversible on podzol and mostly irreversible on chernozem. From the magnitude of the $R_{d}$ values the following order of influence on $\mathrm{I}^{-}$ion sorption is deduced: $\mathrm{CN}^{-}>\mathrm{NO}_{3}^{-} \simeq \mathrm{Cl}^{-}$ $\simeq \mathrm{SO}_{4}^{2-}>\mathrm{Br}^{-}$for chernozem, and $\mathrm{Cl}^{-}>\mathrm{SO}_{4}^{2-}>$ $\mathrm{NO}_{3}^{-} \simeq \mathrm{CN}^{-}>\mathrm{Br}^{-}$for podzol.

The results of the exchange experiments are given in Table 3 . The observation that in both soil types the exchange ratio $R_{d, \text { ex }}$ is very small and of about the same magnitude, is quite striking. Not much exchange seems to take place between radioactive $\mathrm{I}^{-}$and inactive $\mathrm{I}^{-}$ ion. One would have expected $R_{d}$ values of comparable 

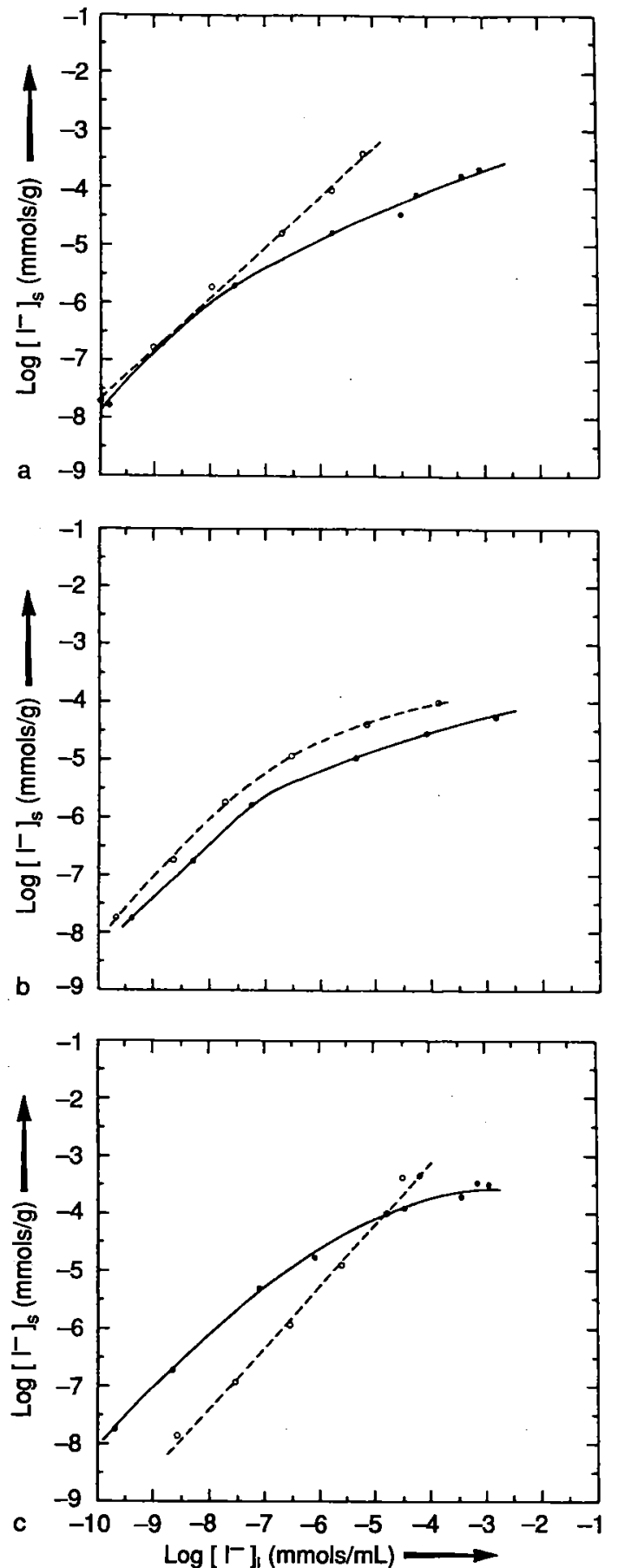

Fig. 5. Sorption isotherms for Chernozem soil. a) synthetic soil water; b) rainwater; c) bidistilled water; adsorption; O desorption.

magnitudes as those obtained from the desorption experiments. Negligibly small $R_{d, \text { ex}}$-values observed are difficult to understand and to explain, especially for lower inactive $\mathrm{I}^{-}$concentrations.

In another set of experiments the nature of the humic substances in the solid particles and their role in the adsorbing, desorbing and exchange processes were determined. Enough conc. $\mathrm{HCl}$ was added to the solutions to reduce the $\mathrm{pH}$ to about 2 . After filtration the activity change in the liquid phases was determined. Part of the activity was precipitated with the
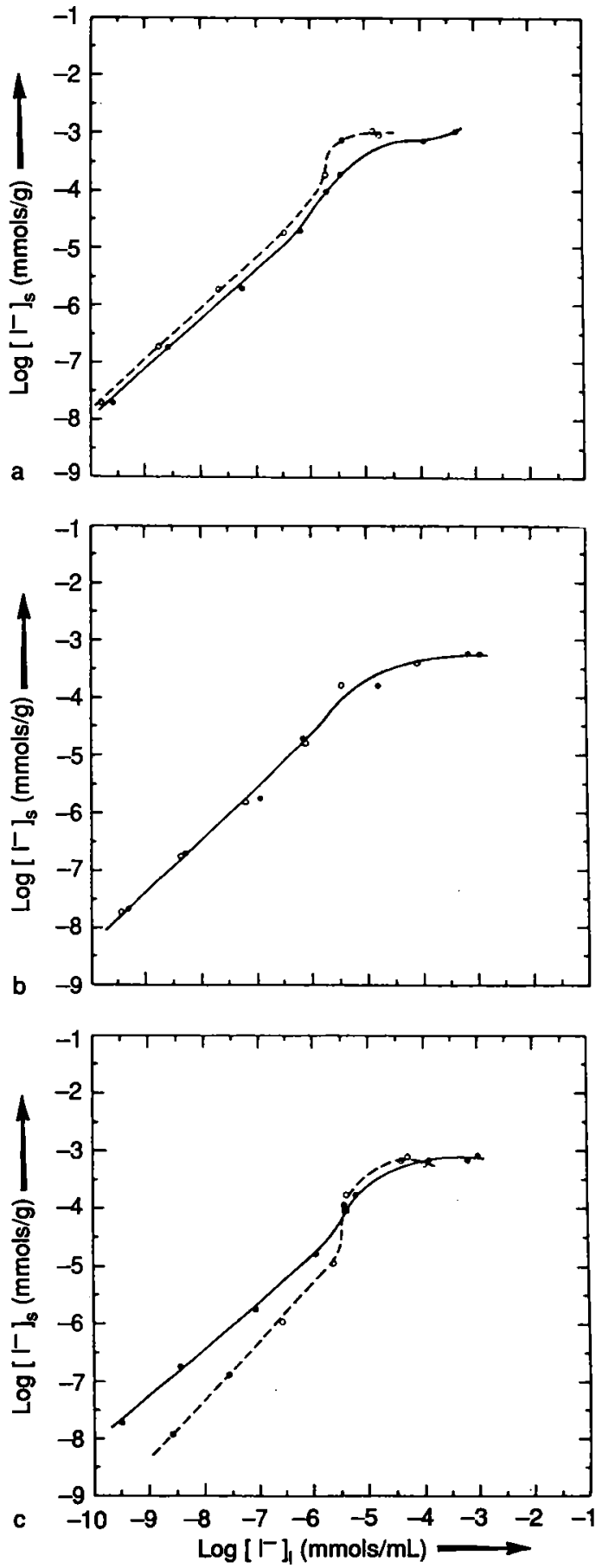

Fig. 6. Sorption isotherms for Podzol soil. a) synthetic soil water; b) rainwater; c) bidistilled water; adsorption; $O$ desorption.

humic acids, while the humic substances not precipitated represent lower molecular weight fulvic acids. To determine the various components of the humic substances on the soil particles, $0.5 \mathrm{M} \mathrm{NaOH}$ solution was added to the solid phase following desorption. After phase separation, again concentrated $\mathrm{HCl}$ was added to the liquid phase. The precipitate consisted of humic acids and was separated from the solution containing fulvic acids by centrifugation. Humic substances present on the soil particles after $\mathrm{NaOH}$ treatment were insoluble humins. The results of humic 


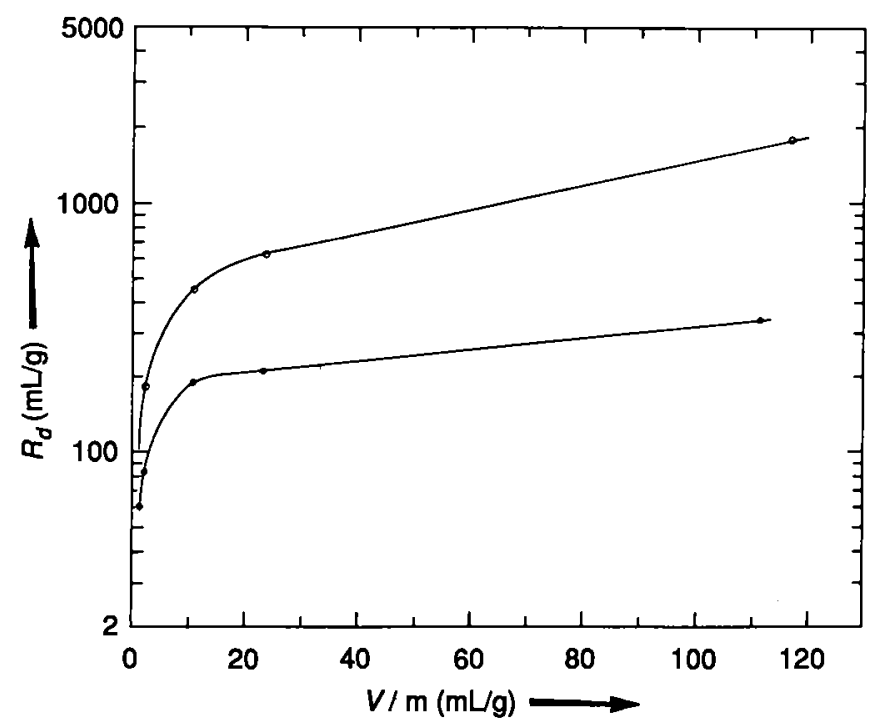

Fig. 7. Sorption of $\mathrm{I}^{-}$ion in synthetic soil water onto Chernozem and Podzol as function of volume to mass ratio, $\mathrm{V} \cdot \mathrm{m}^{-1}$. - Podzol; O Chernozem.

Table 3. Exchange behaviour of $\mathrm{I}^{-}$ion on Podzol and Chernozem with no $\mathrm{I}^{-}$carrier added radioactive ${ }^{125} \mathrm{I}$ tracer

\begin{tabular}{lccc}
\hline \multirow{2}{*}{$\begin{array}{l}\text { Exchange } \\
\text { solution }\end{array}$} & $\begin{array}{c}\left(\mathrm{I}^{-}\right)_{\text {inactive }}^{0} \\
\left(\mathrm{~mol} \cdot 1^{-1}\right)\end{array}$ & \multicolumn{2}{c}{ Soil type } \\
\cline { 3 - 4 } & & $\begin{array}{c}\text { Chernozem } \\
R_{\text {d, ex }}\end{array}$ & $\begin{array}{c}\text { Podzol } \\
R_{d, \text { ex }}\end{array}$ \\
\hline Bidistilled & $1.0 \cdot 10^{-4}$ & 0.4 & 0.2 \\
water & $1.0 \cdot 10^{-5}$ & 0.4 & 0.5 \\
& $1.0 \cdot 10^{-6}$ & 0.1 & 0.4 \\
SSW & $1.0 \cdot 10^{-8}$ & 0.1 & 0.3 \\
& $1.0 \cdot 10^{-8}$ & 0.3 & 0.3 \\
\hline
\end{tabular}

component determination of the soil particles and in the adsorbing desorbing and exchange solutions are given in Tables 4 and 5, respectively. In Table 4 it is seen that the percentage of fulvic acid is higher in both soil types in the sorbing solution. This is expected as the lower molecular weight fulvic acids dissolve more easily in water. On the other hand in the study of humic components of the soil particles it is seen that podzol type soil contains more humic and fulvic acids than humins, whereas chernozem contains less acids and more humins. This can be explained by the higher amount of organio-mineral compounds due to the higher clay content and a higher biological activity and not at least to the history of the soil formation of the chernozem. Humins are very stable and are poorly extractable with $\mathrm{NaOH}$. In absolute terms (Table 1) chernozem type soils contain more organic components and biomass than podzol soils. This reflects the higher $R_{d}$ values in $\mathrm{I}^{-}$ion sorption on chernozem soils.

The results of sorption of $\mathrm{I}^{-}$ion on various kinds of clay minerals are given in Table 6 . The very small $R_{d}$ values observed, when compared to those obtained for chernozem and podzol soils, indicate that the role of inorganic components in the sorption of $\mathrm{I}^{-}$is very
Table 4. Humic components in the sorption solution

\begin{tabular}{|c|c|c|c|c|}
\hline \multirow[t]{3}{*}{ Solution used } & \multicolumn{4}{|c|}{ Soil type } \\
\hline & \multicolumn{2}{|c|}{ Chernozem } & \multicolumn{2}{|c|}{ Podzol } \\
\hline & $\begin{array}{l}\% \text { Humic } \\
\text { acid }\end{array}$ & $\begin{array}{c}\% \text { Fulvic } \\
\text { acid }\end{array}$ & $\begin{array}{l}\% \text { Humic } \\
\text { acid }\end{array}$ & $\begin{array}{c}\% \text { Fulvic } \\
\text { acid }\end{array}$ \\
\hline $\begin{array}{l}\text { Adsorption } \\
\text { solution }\end{array}$ & - & - & 39 & 61 \\
\hline $\begin{array}{l}\text { Desorption } \\
\text { solution }\end{array}$ & 39 & 61 & 30 & 70 \\
\hline $\begin{array}{l}\text { Exchange } \\
\text { solution }\end{array}$ & 32 & 68 & 25 & 75 \\
\hline
\end{tabular}

Table 5. Humic components of the soil particles after desorption (Original amount of humics of soil is taken as $100 \%$ )

\begin{tabular}{lcc}
\hline Humic substances (\%) & \multicolumn{2}{c}{ Chernozem Podzol } \\
\hline Dissolved by NaOH & & \\
$\quad$ (Humic and fulvic acids) & 37 & 59 \\
Undissolved by NaOH (Humins) & 63 & 41 \\
Precipitate with conc. HCl (Humic acid) & 16 & 35 \\
Not precipitated with conc. HCl & 21 & 24 \\
$\quad$ (Fulvic acid) & & \\
\hline
\end{tabular}

Table 6. Sorption of $\mathrm{I}^{-}\left(R_{d}\right.$ in $\left.\mathrm{ml} \cdot \mathrm{g}^{-1}\right)$ on various clay minerals (Means of triplicate determination)

\begin{tabular}{|c|c|c|c|c|}
\hline \multirow[t]{2}{*}{ Clay type $/ \mathrm{C}_{\text {org }} \%$} & \multicolumn{2}{|c|}{ Bidistilled water } & \multicolumn{2}{|c|}{ Synthetic soil water } \\
\hline & $R_{d}$ (Ads.) & $R_{d}$ (Des.) & $R_{d}$ (Ads.) & $R_{d}$ (Des.) \\
\hline $\begin{array}{l}\text { Koalinite/ } \\
0.04\end{array}$ & 0.5 & 1.4 & 0.6 & 1.7 \\
\hline $\begin{array}{l}\text { Montmorillonite/ } \\
0.13\end{array}$ & 0.2 & 0.2 & 0.6 & 1.7 \\
\hline $\begin{array}{l}\text { Chlorite-illite/ } \\
1.27\end{array}$ & 5.0 & 18.2 & 1.4 & 6.2 \\
\hline
\end{tabular}

Table 7. Distribution ratios ( $R_{d}$-values) of iodine in a Chernozem and in a Podzol incubated under different conditions

\begin{tabular}{lcr}
\hline Incubation condition & \multicolumn{2}{c}{$R_{d}$-values } \\
\cline { 2 - 3 } & Chernozem & \multicolumn{1}{c}{ Podzol } \\
\hline Insterile, aerobic & $317.3 \pm 25.0$ & $73.0 \pm 7.3$ \\
Insterile, anaerobic & $26.7 \pm 4.2$ & $36.3 \pm 6.2$ \\
Sterile $\left({ }^{60} \mathrm{Co}\right)$ & $1.8 \pm 0.03$ & $4.3 \pm 0.5$ \\
Sterile $(\mathrm{CHCl})$ & $6.2 \pm 0.5$ & $11.1 \pm 2.6$ \\
\hline
\end{tabular}

small. Chloride-illite type clays with a higher content of organic carbon sorb more iodide than koalinite and montmorillonite clays, the sorption process seems to be irreversible for clays.

\subsection{Effects of soil biomass}

As shown in Table 7 the sterilization of soils caused a considerable decrease of the $R_{d}$-values in both soil 


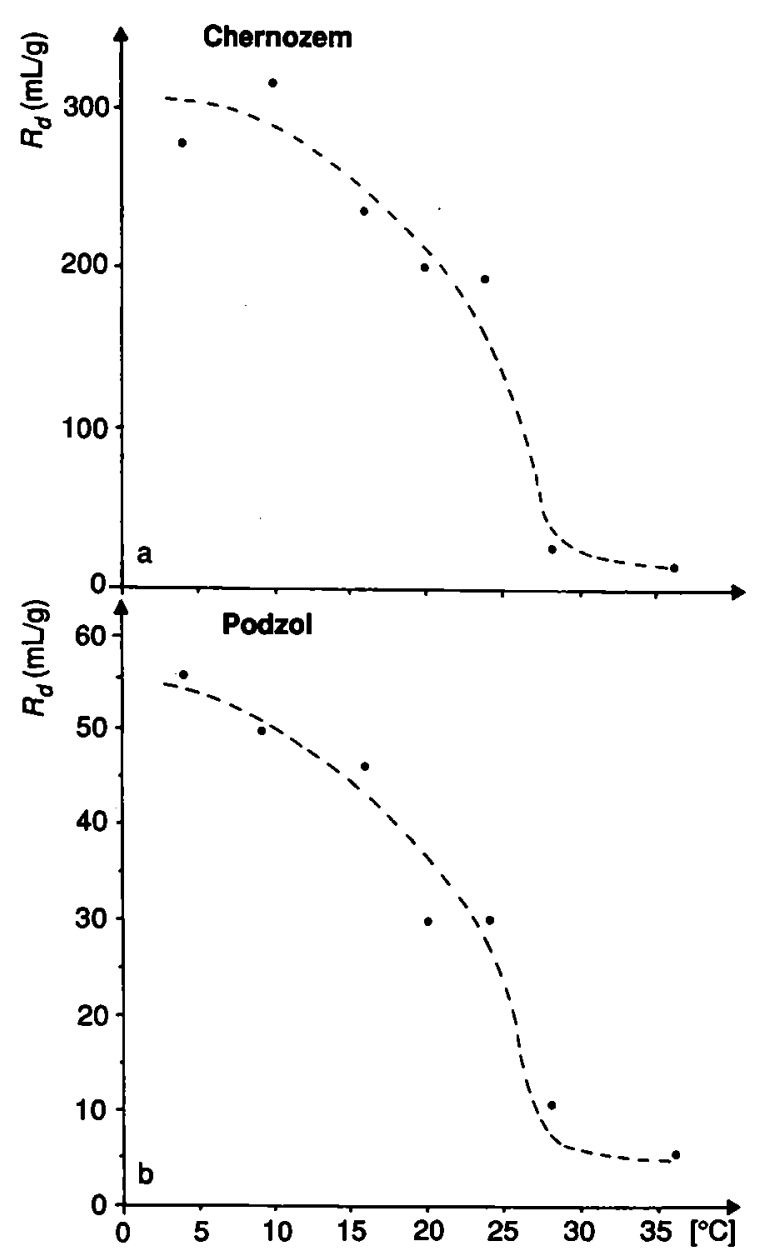

Fig. 8. $\boldsymbol{R}_{\mathrm{d}}$-values of radioiodine in Chernozem (a) and Podzol (b) related to different incubation temperatures.

types. The ${ }^{60} \mathrm{Co}$ gamma-irradiation was more effective than the $\mathrm{CHCl}_{3}$-fumigation. Incubation of soil samples under anaerobic conditions $\left(\mathrm{N}_{2}\right.$-atmosphere) also caused a reduced iodine fixation, e.g. about $50 \%$ reduction of the $R_{d}$-values in the podzol and more than $90 \%$ reduction in the chernozem, indicating that iodine fixation may be mediated by enzyme systems (iodine oxidase) associated with microbial metabolism as was suggested elsewhere $[9,11]$. In general, the treatments were more effective in the chernozem than in the podzol. These results support the validity of the assumption that soil biomass is participating in iodine immobilization mechanisms.

Another indication for biologically mediated processes is the observed dependence on the incubation temperature. Biologically catalyzed reactions principally show a more or less sharp temperature optimum and fall off when the temperature is increased beyond this point. There is an obvious dependence of iodine fixation on the incubation temperature as demonstrated in Fig. 1. However, the expected temperature optimum did not appear in this investigation. The highest iodine fixation was observed at relatively low temperatures $\left(4^{\circ} \mathrm{C}\right.$ and $10^{\circ} \mathrm{C}$ respectively) and it is remarkable that $R_{d}$-values decrease considerably above $28^{\circ} \mathrm{C}$. Soil biomass is most stable in lower tem-

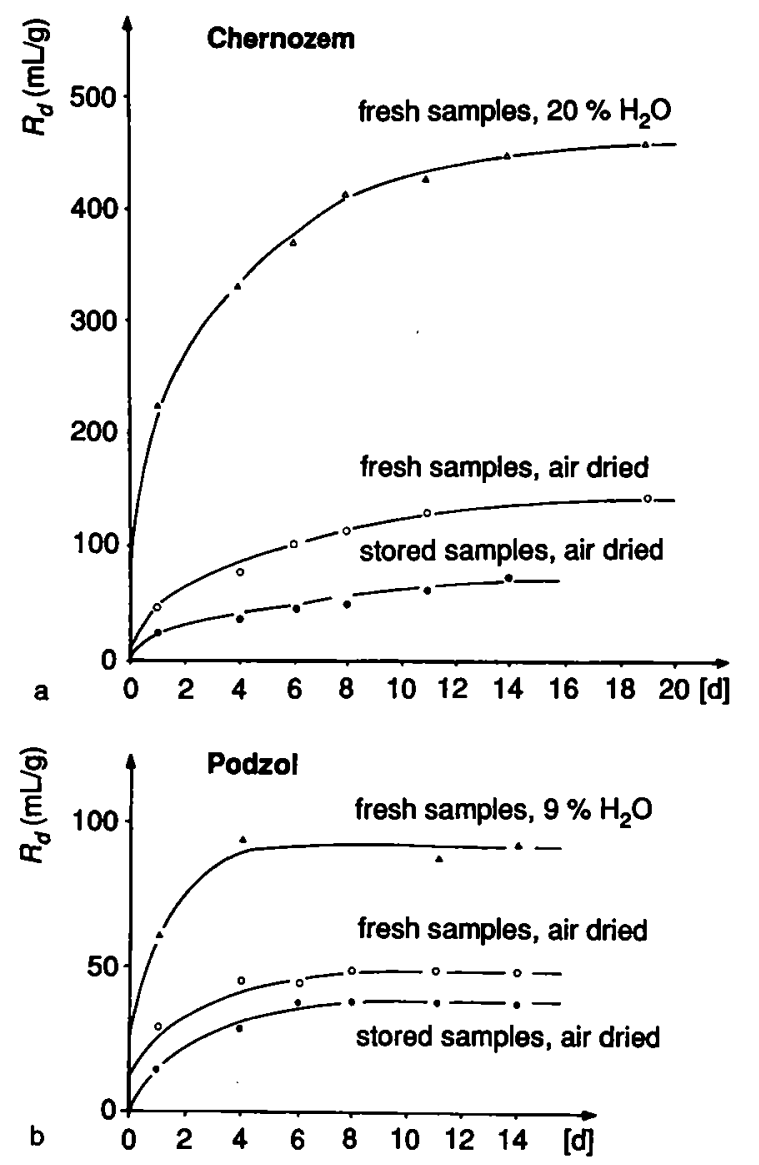

Fig. 9. $R_{d}$-values of radioiodine in Chernozem (a) and Podzol (b) resulting from different treatments before incubation.

perature regions and will be slowly degraded when the temperature increases as was demonstrated by Anderson and Domsch [15]. Therefore it can be concluded, that resulting $R_{\mathrm{d}}$-values are related to the temperature dependent survival of microorganisms. However, some influence of the temperature on the binding of iodine to soil itself must be considered also.

The experiments on the effects of soil moisture and storage conditions exhibited significant differences in the kinetics of iodine sorption (Fig. 9). Immobilization of radioiodine in soil samples of medium moisture content occurred at a much higher rate and intensity than in samples which had beeu previously air-dried. The lowest rate was observed in soil samples stored under room conditions for about one year. The natural process of drying is known to reduce microbial biomass content $[16,17]$. Therefore the results support the assumption that iodine sorption is associated with the number of microorganisms and they emphasize the importance of the history and storage conditions of the soil material under investigation.

The effect of increased and reduced soil biomass on the $R_{d}$-values of chernozem and podzol is shown in Table 8 . The data show that $R_{d}$-values are highly influenced by the quantity of soil biomass. The effects are more pronounced in chernozem (higher biomass content) than in the podzol. In chernozem, for example, the correlation between soil biomass and $R_{d-}$ 
Table 8. Effects of increased and reduced contents of soil biomass on the $R_{d}$-values in a chernozem and in a podzol. Values of the normal biomass and corresponding $\boldsymbol{R}_{d}$-values are set in blod

\begin{tabular}{|c|c|c|c|c|c|c|c|}
\hline \multicolumn{4}{|c|}{ Chernozem } & \multicolumn{4}{|c|}{ Podzol } \\
\hline \multicolumn{2}{|c|}{ Soil biomass } & \multicolumn{2}{|c|}{$\boldsymbol{R}_{\boldsymbol{d}}$-values } & \multicolumn{2}{|c|}{ Soil biomass } & \multicolumn{2}{|c|}{$R_{d}$-values } \\
\hline$\mu \mathrm{gC} / \mathrm{g}$ d.w. & relative & absolute & relative & $\mu \mathrm{gC} / \mathrm{g}$ d.w. & relative & absolute & relative \\
\hline 13 & 4 & $21 \pm 1 a^{*}$ & 8 & 3 & 2 & $9+1 \mathrm{a}$ & 30 \\
\hline 27 & 9 & $25 \pm 1 \mathrm{~b}$ & 9 & 11 & 8 & $14 \pm 1 \mathrm{e}$ & 45 \\
\hline 317 & 100 & $276 \pm 12 c$ & 100 & 142 & 100 & $31 \pm 2 c$ & 100 \\
\hline 431 & 136 & $375 \pm 22 d$ & 136 & 199 & 140 & $36 \pm 2 d$ & 115 \\
\hline 546 & 172 & $385 \pm 19 d$ & 139 & 232 & 163 & $37 \pm 4 d$ & 118 \\
\hline 716 & 226 & $376 \pm 30 d$ & 136 & 292 & 206 & $45 \pm 4 d$ & 144 \\
\hline
\end{tabular}

* Values followed by the same letter are not significantly different $(\mathrm{p}=<5 \%)$.
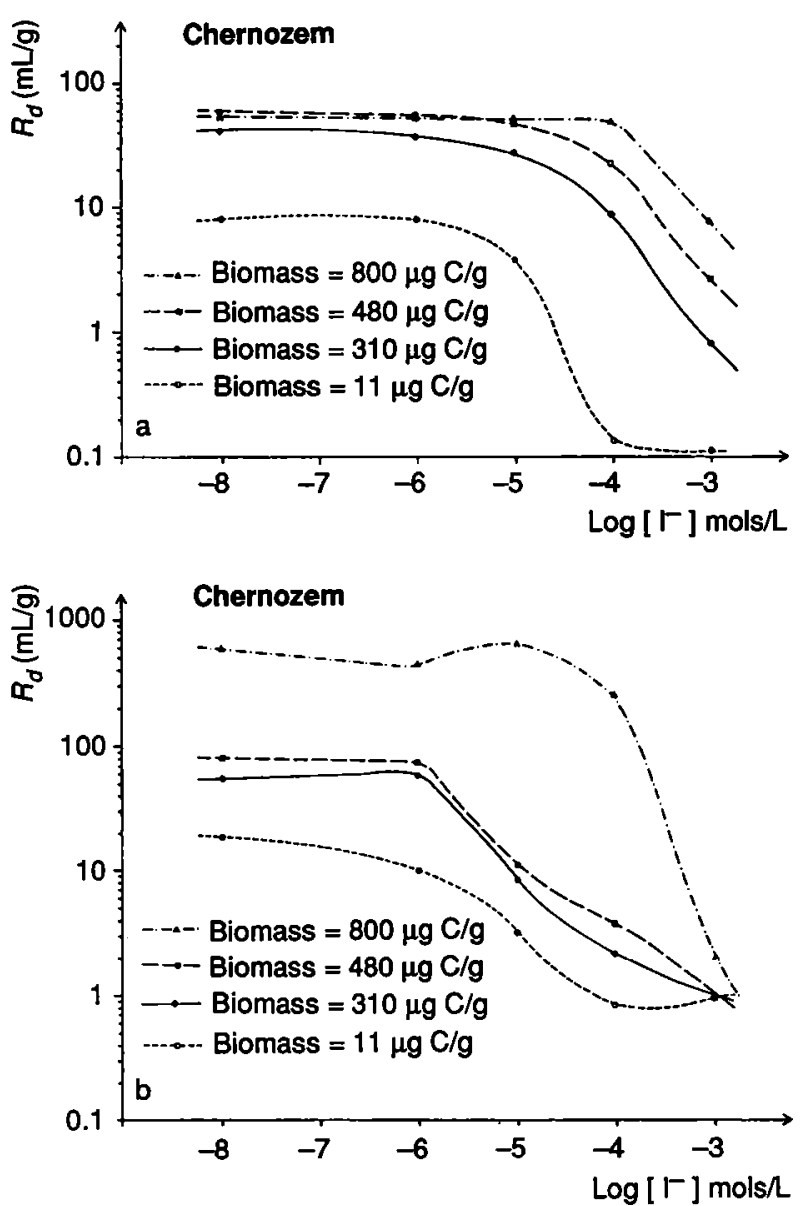

Fig. 10. Interaction of soil biomass content and carrier $\mathrm{I}^{-}$concentration of the equilibrium solution (a: bidistilled water, $b$ : synthetic soil water) in radioiodine immobilization $\left(R_{d}\right.$-values).

value is linear in the range from 4 to $136 \%$ of its original content. A further increase of soil biomass is ineffective, indicating depletion of the radioiodine applied.

To test this assumption experiments were carried out with the addition of carrier iodine in concentrations up to $10^{-3} \mathrm{mols} \cdot 1^{-1}$ using distilled water and synthetic soil water as equilibrium solutions respectively. As indicated by Fig. 10a the highest level of
Table 9. Removal of ${ }^{125} \mathrm{I}$ from $\mathrm{H}_{2} \mathrm{O}, \mathrm{CaCl}_{2}$ or $\mathrm{NaCl}$ solution by different soil bacteria and fungi

\begin{tabular}{lccc}
\hline \multirow{2}{*}{ Microbial genus } & \multicolumn{3}{c}{$\%$ Removal of ${ }^{125} \mathrm{I}$} \\
\cline { 2 - 4 } & $\mathrm{H}_{2} \mathrm{O}$ & $\begin{array}{c}\mathrm{CaCl}_{2} \\
(0.01 \mathrm{M})\end{array}$ & $\begin{array}{c}\mathrm{NaCl} \\
(0.15 \mathrm{M})\end{array}$ \\
\hline Enterobacter & 0 & 0 & 71 \\
Bacillus & 0 & 33 & 66 \\
Pseudomonas & 0 & 0 & 57 \\
Thielaviopsis & 0 & 35 & 41 \\
Verticillium & 0 & 5 & 16 \\
Fusarium & 35 & 28 & 21 \\
Trichoderma & 31 & 23 & 12 \\
Penicillium & 35 & 10 & 5 \\
\hline
\end{tabular}

sorption was found when biomass was increased by $50 \%\left(480 \mu \mathrm{g} \mathrm{C} \cdot \mathrm{g}^{-1}\right)$ and remained nearly constant over a concentration range up to $10^{-5} \mathrm{~mol} \cdot 1^{-1}$. Also in these concentration range the highest biomass con-

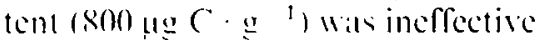

At higher concentrations $\left(10^{-4}\right.$ to $\left.10^{-3} \mathrm{mols} \cdot 1^{-1}\right)$ $R_{d}$-values show a clear dependence on the biomass content; i.e. soil samples with a considerably increased biomass content have the capability to fix radioiodine with increased efficiency. These sorption characteristics are much more pronounced if soil samples are incubated in synthetic soil water (Fig. 10b). In this case the sorption of radioiodine depended clearly on the soil biomass content throughout the whole concentration range. Especially high iodine amounts were immobilized in soil samples with the highest biomass content $\left(800 \mu \mathrm{g} \mathrm{C} \cdot \mathrm{g}^{-1}\right)$.

On the basis of these observations the role of soil microorganisms in iodine immobilization is emphasized, but the ionic composition (physico-chemical soil properties) of the soil solution may be of additional importance. Cations for example influence the solubility of humic acids by forming "humates".

The incorporation experiments with single isolated soil microorganisms revealed that both bacteria and fungi were unable to remove radioiodine from the nutrient media, irrespective of the composition of the 
media and irrespective whether iodine was applied from the beginning of the culture or to the already existing biomass (data not shown). This failure of iodine uptake might be due to the formation of nonavailable iodine complexes with the nutrients or/ and with substances exuded from the cells. However, a significant fraction of iodine was removed by the washed cells free of culture media (Table 9). The highest uptake was observed when bacterial cells were exposed to an isotonic $\mathrm{NaCl}$-solution containing the radioiodine. After suspension of cells in $\mathrm{H}_{2} \mathrm{O}$-solution only Fusarium sp., Trichoderma sp. and Penicillium $\mathrm{sp}$. were effective in removing radioiodine. Using $\mathrm{CaCl}_{2}$ as an electrolyte fungal cells and Bacillus sp. incorporated radioiodine at a low to medium extent.

Though demonstrating, that radioiodine can be incorporated into soil biomass under certain conditions, these findings provide only limited evidence whether soil microorganisms participating in iodine immobilization act in a direct or an indirect way. It should be considered in this connection, that the experimental conditions used differed in may respects from natural soil conditions. Further, the microorganisms tested represented only a small part of the soil microflora and they will behave differently in pure cultures than in complex soil environment.

\section{Acknowledgements}

The authors thank A. Kremling and H. Wiener for skilled technical assistance and Prof. Dr. E.-G. Niemann for reading and improving the manuscript.

\section{References}

1. Bors, J., Martens, R., Kühn, W.: Radiochim. Acta 44/45, 147 (1988)

2. Lieser, K.-H., Steinkopff, Th.: Radiochim. Acta 46, 49 (1989).

3. Whitehead, D. C.: J. Soil Sci. 29, 88 (1978).

4. Whitehead, D. C.: J. Sci. Food Agric. 25, 73 (1974).

5. Allard, B., Torstenfelt, B., Andresson, K., Rydberg, J.: Scientific Basis for Nuclear Waste Management, Vol. 2, Ed. by C. J. M. Northrup J.r., Plenum Press, N.Y. p. 673 (1980).

6. Strickert, R., Friedman, A. M., Friend, S.: Nucl. Technol. 49, 253 (1980).

7. Sass, A.: Radioprotection 11, 205-217 (1976).

8. El-Kekli, A. T., Johannson, K. J.: Proc. of a Seminar in Terrestrial Radioecology, Uppsala, Sweden (Ed. A. Eriksson), July 8-11, 1985.

9. Christiansen, J. V., Carlsen, L.: Iodinated humic acids. (Presented at the International Symposium on Humic Substances in the Terrestrial and Aquatic Environment, Linköping, August 1989), in press.

10. Strack, S., Müller, A.: Proc. from UIR Workshop "Role of microorganisms on the behaviour of radionuclides in aquatic and terrestrial systems and their transfer to man", Brussels, Belgium (Ed. by E. Bonnyus-van Gelder and R. Kirchmann) April 25-27, 1984).

11. Behrens, H., in: The Effects of Natural Organic Compounds and of Microorganisms on Radionuclide Transport. Radioactivity Waste Management Committee OECD Nuclear Energy Agency, Paris 1986.

12. Bunzl, K., Schimmak, W.: Radiation and Environmental Biophysics 27, 165 (1988).

13. Erten, H. N., Aksoyoglu, S., Gökturk, H.: The Science of the Total Environment 69, 269 (1988).

14. Jenkinson, D. S., Powlson, D. S.: Soil Biology and Biochemistry, 8, 209 (1976).

15. Anderson, T. H., Domsch, K. H.: Biol. Fert. Soils 1, 81 (1985).

16. Birch, H. F.: Plant and Soil 12, 81 (1960).

17. Powlson, D. S., Jenkinson, D. S.: Soil. Biol. and Biochem. 8, 179 (1976). 
Brought to you by | Bilkent University

Authenticated

Download Date | 12/7/18 6:05 PM 